\title{
Komentarze
}

\section{Nowa Humanistyka i odpowiedzialność za ciągłość (dawnej) tradycji}

Marcin Cieński

TEKSTY DRUGIE 2017, NR 1, S. 235-243

DOI: $10.18318 /$ td.2017.1.19

Dostawy badawcze, które sytuują się w kręgu Nowej Humanistyki, są dziś dla szerszego grona polskich akademickich badaczy literatury niełatwo rozpoznawalne i niełatwo identyfikowalne. Problem stanowiłoby już wskazanie tekstów-manifestów Nowej Humanistyki, jej instytucjonalność znajduje się w fazie (zapewne) początkowej (względnie, jeśli wiązać ją z działaniem transdyscyplinarnych szkół doktoranckich - w momencie przełomu), kryteria włączania do tego obszaru badaczy i ich prac nie są powszechnie znane. Całe zjawisko wydaje się mieć kształt mgławicowy (określenia tego w żadnym razie nie należy traktować jako zarzutu, podkreśla ono trudności stojące przed zewnętrznym obserwatorem), identyfikowane jest/może być poprzez osoby, badaczy czy ich kręgi, relacje, związki.

Narzuca się tu porównanie z działającym laboratorium, które znajduje się w fazie oczekiwania na wynik aplikacji o duży grant, przygotowanej solidnie, innowacyjnej (zgodnie z zaleceniami), ale obarczonej znacznym ryzykiem odrzucenia (jak zwykle w konkursach). Oczywiście wnioskodawcy są przekonani o słuszności
Marcin Cieński - dr hab., profesor UWr., pracuje w Instytucie Filologii Polskiej; członek Rady Naukowej IBL PAN oraz redakcji "Wieku Oświecenia". Historyk literatury, komparatysta. Opublikował ostatnio: Literatura polskiego oświecenia wobec tradycji i Europy: studia (2013), Humanizm polski i wspólnoty: naród - społeczeństwo państwo - Europa (red.) (2010); Kontakt: marcin.cienski@uwr. edu.pl 
projektu, wskazują na wagę dotychczasowych rezultatów, kreślą możliwości, ale jednocześnie widzą, że niedługo strumień pieniędzy się skończy, liderzy ekipy się wyłonili, ale nie zostali jeszcze formalnie zatwierdzeni, a co gorsza, uczestnicy projektu zaczynają sobie uświadamiać, że ich entuzjazm i zdolność wprowadzania nowych obszarów badań są wyraźnie skorelowane z rezultatami konkursu grantowego. I dopiero otrzymanie finansowania pozwoli całej ekipie na uporządkowanie sytuacji i sprawdzenie potencjału w działaniu.

Jednak w przypadku Nowej Humanistyki nie zapowiada się, by w razie chwilowego niepowodzenia miało dojść do upadku projektu i rozpadu związanego z nim zespołu, raczej będzie się on rekonfigurował, inaczej niż wówczas, gdyby uzyskał instytucjonalną legitymizację. Niewiele jednak można powiedzieć o ewentualnych wynikach tych przeobrażeń, gdyż w gruncie rzeczy zbyt mało wiemy o współczesnych sposobach tworzenia się szkół badawczych czy nawet skromniej - zespołów czy grup badawczych - w dziedzinie szeroko rozumianej humanistyki, zwłaszcza w warunkach przemian systemowych mających wyraźnie nieciągły charakter, jak przez kilkanaście minionych lat działo się w Polsce.

Sytuacja Nowej Humanistyki wydaje się zaś tym bardziej złożona, że w obecnej postaci jest raczej pewnym projektowym amalgamatem (znowu: to nie zarzut), inter- czy raczej transdyscyplinarnym, budowanym wyraźnie ponad tradycyjnymi granicami obszarów badawczych i dyscyplin, przez kreowanie więzi personalnych, tematycznych oraz konsorcjalnych. Zaś rozpoznanie jej miejsca na metodologicznej mapie polonistycznego literaturoznawstwa (to ono bowiem stanowi zasadniczy obszar odniesienia dla dalszych uwag) wydaje się tym trudniejsze, że określenie jego obecnego stanu wydaje się właściwie niemożliwe.

Przyczyną jest tu zarówno wewnętrzna różnorodność środowiska, rozmaitość tematyczna prowadzonych badań, jak i niechęć do składania deklaracji metodologicznych, do ujawniania przynależności do określonego kręgu czy szkoły (choć tu należałoby zauważyć też istnienie ekspansywnej kontrtendencji - rozrostu szeroko zakrojonych metodologicznych czy teoretycznych rozważań w pracach odnoszących się do kwestii jednostkowych). Poza projektem kulturowej teorii - i historii - literatury nie pojawiły się (albo nie ujawniły) w ostatnim czasie wyraziste ogólne projekty metodologiczne, ,samoistnie” (czy odwołując się do wyobraźni Lema: „samowzbudnie”) określające powinności badacza literaturoznawcy, próbujące określić jego tożsamość.

Próby metodologicznego odnowienia dyscypliny są dość częste (choć niesystematyczne i ograniczone w praktyce do badań niektórych epok), wiążą 
się jednak w dużej mierze z tzw. zwrotami lub - co dziś widać coraz lepiej - wpisują się w zespół postaw/metod Nowej Humanistyki, której nie utożsamiałbym z nowoczesną humanistyką, mimo wielu elementów wspólnych. To jednak kwestie zdecydowanie wykraczające poza ramy szkicowego ujęcia. Katalog pytań, jakie można by postawić Nowej Humanistyce - i w związku z nią - jest obszerny; nie chciałbym się zajmować tu sprawami odnoszącymi się do jej statusu oraz specyfiki metod czy sposobów postępowania, wolałbym zwrócić uwagę na odmienne kwestie, zapowiedziane w tytule.

Interesowałoby mnie bowiem, czy przeobrażenia określane jako Nowa Humanistyka otwierają również możliwości odmiennej niż dotychczasowa interpretacji tekstów i zjawisk z zamierzchłej przeszłości. Jednocześnie jednak należałoby zwrócić uwagę na pojawianie się niebezpieczeństwa marginalizowania przez nowoczesne badania utworów czy problemów z obszaru literatury dawnej.

Jednak, by - nawet krótko - zasygnalizować te kwestie, należałoby poczynić jeszcze dwie uwagi odnoszące się do Nowej Humanistyki, do tego, co wydaje mi się, w przyjętej tu perspektywie, w niej najważniejsze.

Po pierwsze, jej pojawienie się zdaje się sygnalizować próbę przejścia w polskiej rzeczywistości od fazy „zwrotów” w szeroko rozumianym obszarze badań humanistycznych (i ich literaturoznawczej aplikacji) do fazy dążeń do stworzenia projektu integralnego, całkowitego (niemającego jednak oznaczać ujednolicenia). W ten sposób kolejny projekt powraca w pewien szczególny sposób - a przydarza się to w badaniach humanistycznych co pewien czas - do źródeł, czyli do renesansowego humanizmu, rozumianego jednocześnie i jako program antropologiczny, i jako sposób odnoszenia się do rzeczywistości, jako zespół umiejętności „technicznych” z zakresu filologii. Poszczególne zwroty, o których ważności, specyfice i hierarchii dyskutowano jeszcze niedawno (a debaty te przecież nie całkiem wygasły), w ujęciu Nowej Humanistyki zdają się tracić autonomię, przestają stanowić czynnik jednostronnie przekształcający procedury badawcze, „otwierający oczy” na jeden $\mathrm{z}$ aspektów/wymiarów kultury.

Ich znaczenie dla całego projektu jest różne, część z nich stanowi metodologiczny podkład, niektóre natomiast nie wchodzą w obręb tego nowego poruszenia badawczego, względnie odgrywają rolę marginalną. Nie wydaje się przy tym prawdopodobne zastąpienie kierunków badań budowanych w ramach poszczególnych zwrotów przez całościowy sposób prowadzenia refleksji proponowany przez Nową Humanistykę (niezależnie od jego wewnętrznej różnorodności). 
Druga uwaga dotyczy przedmiotu badań Nowej Humanistyki. Jak się wydaje, projekt ten w obecnej postaci zasadniczo koncentruje się na, szeroko rozumianej, współczesności naszego stulecia i powojennej połowy poprzedniego (mówiąc inaczej: znane mi prace dotyczą właśnie tego okresu). W konsekwencji jest wyraźnie zorientowany na przemiany zachodzące od kilkunastu/kilkudziesięciu lat i na analizę materiału aktualnego, którego nie oddziela od badacza wyraźny dystans czasowy. Nie zmienia tego fakt, że w kategoriach doświadczenia osobistego czy generacyjnego bywa to odległość znaczna; często oczywista jest odmienność doznawania świata przez badacza i tego, jakie było udziałem badanych przez niego osób czy autorów interpretowanych przez niego dzieł, a bariera oddzielająca te doznania okazuje się bardzo wyrazista.

Natomiast obszarem odniesienia dla tych sposobów postępowania nie staje się na ogół literatura i kultura dawniejsza, mówiąc inaczej: aktualna współczesność jest objaśniana przez współczesność, nowoczesność po przełomie modernistycznym - przez nią samą, znika natomiast wczesna nowoczesność, znika początek świata nowożytnego, znika świadomość tego, że tradycja może odznaczać się długim trwaniem, zaprzestaje się szukania w dalszej przeszłości nawet takiej tradycji, na którą składano (inna sprawa, słusznie czy nie) pewną część odpowiedzialności za zbrodnie i występki współczesności (np. wskazując oświeceniowe procesy laicyzacyjne jako źródło etycznego i aksjologicznego kryzysu świata nowoczesnego).

Dawna rzeczywistość literacka, kulturowa, ideologiczna oraz jej trwanie w charakterze tradycji powinny zostać poddane oglądowi przez Nową Humanistykę przede wszystkim dlatego, że humanistyka jako taka nie może odpowiedzialnie podejmować się opisu i diagnozowania zjawisk zachodzących w publicznej przestrzeni współczesności bez uwzględnienia ich antecedencji. Ujmując rzecz inaczej - programowe (czy praktyczne, to wszystko jedno) désintéressement dla tradycji uderza w podstawy myślenia o współczesności, której obraz nosi w konsekwencji ślady (może nawet nieusuwalne) wyobcowania badacza z kulturowej ciągłości, jego ahistorycznej postawy.

Ujmując zaś rzecz szerzej, spojrzenie w takiej perspektywie, zdominowanej przez wizję współczesności zapętloną na tłumaczeniu siebie sobą, oznaczać może nie tylko reorganizację badań, stworzenie wykorzenionego z historii laboratorium, ale również przetworzenie zbiorowej pamięci i wyobraźni nie wskutek działania naznaczonego ideologią, ale wskutek stosowania obarczonego wadą instrumentarium. Choć pozwala ono w wielu kwestiach 
dotyczących współczesności na odkrywcze rewizje, odsłonięcie niespodziewanego czy zatartego, jednocześnie - jeśli stosować je bez uwzględnienia historycznego komponentu - wzmacniać może (i zapewne będzie) pęknięcie, oddzielanie się współczesności od przeszłości, niezależnie od tego, gdzie usytuujemy granicę między nimi.

Widoczny dysonans między instrumentarium pojęciowym i technicznym nowej humanistyki a badaniami dawnej literatury i kultury nakazuje ostrożność. Nakazuje również postawienie pytania o możliwości aplikacji metod Nowej Humanistyki do badań nad literaturą dawną (do końca XVIII wieku) i o pożytki z takiego postępowania. Kwestia ta wiąże się bezpośrednio z problematyką odpowiedzialności za kształcenie na studiach polonistycznych (filologicznych, kulturoznawczych), kształcenie, które powinno być podejmowane w taki sposób, by nie dochodziło do destrukcji wypracowanych metod lektury i rozumienia tekstów dawnych, by nie doszło do zerwania ciągłości literackiej i kulturowej tradycji.

Spojrzenie z perspektywy badacza dawnej literatury i kultury, zajmującego się przeważnie zjawiskami zachodzącymi do końca oświecenia (do ok. 1820/1830 roku), jasno ukazuje, że niemożliwe jest pełne zastosowanie w ich oglądzie rozwiązań przyjmowanych w obrębie Nowej Humanistyki. Wykluczone są chociażby - co dość oczywiste - powiązania praktyki badawczej $\mathrm{z}$ artystyczną, próby wymiany doświadczeń: tym samym nie może być więc mowy o humanistyce współ-tworzącej, ale badacz musi pozostać w kręgu procedur rekonstrukcyjnych.

Zasadnicza wydaje się tu kwestia narzędzi czy metod, jakie się stosuje, by odtworzyć - i zrozumieć - teksty dawne, sposób myślenia, z którego wyrastają. Na te działania wpływa świadomość czasowego dystansu wykluczającego odwoływanie się do bezpośredniego badania nie tylko żywego doświadczenia czy pamięci, ale także, niejednokrotnie, usłyszenie głosu milczących milionów zmarłych, niepiśmiennych, pozbawionych możliwości sformułowania utrwalonego świadectwa, usuniętych z pamięci lub skazanych na występowanie w niej za pośrednictwem cudzego głosu, a raczej pióra. Istniejące teksty i dokumenty są fragmentem większej całości: nie wiemy nawet, jak rozległej, w jakich miejscach niepełnej (oczywiście ta niewiedza w różnym stopniu dotyczy poszczególnych epok i miejsc).

Jednakże mimo tych (nieuniknionych) luk badacze epok dawnych podejmują mozolne rekonstrukcje, próby rozumienia, wzbogacania wiedzy dążą w konsekwencji do nakreślenia czy raczej dopełnienia linii tradycji od czasów „początkowych” po współczesność. Te działania - służące szeroko 
rozumianemu uświadamianiu fundamentu kulturowego, również aksjologicznego - dokonują się w praktyce (polskiego literaturoznawstwa zajmującego się epokami dawniejszymi) najczęściej w zgodzie z pewnym ogólnie przyjętym i aprobowanym sposobem postępowania badawczego, na ogół dalekim od eksponowania problemów metodologicznych.

W badaniach epok dawnych prowadzonych w Europie Zachodniej nowoczesność metodologiczna pojawia się zdecydowanie częściej niż w polskich, jednak na ogół z wyraźną rozwagą, umiarem. Przykładem niech będzie tu przedstawienie współczesnych badań nad oświeceniem wypełniające główną część rocznika „Dix-Huitième Siècle” z 2014 roku, gdzie dużo miejsca - po tekstach dotyczących głównych kierunków badań - poświęcono kwestiom edycji (w tym genetycznych i cyfrowych), zastosowaniu metod numerycznych, badaniom nad kobietami, ekonomią, drukiem i publicznością oraz interdyscyplinarności; m.in. Glenn Roe i Benoît Melançon pisali o możliwościach stwarzanych przez cyfryzację dla badaczy XVIII stulecia, a Maria Leca-Tsiomis o dobrym użytku z informatyki.

W polskich badaniach nad literaturą dawną nie pojawiają się zasadniczo postulaty dotyczące wyraźnej zmiany metodologicznej. Stosunkowo często dochodzą do głosu i znajdują zastosowanie w praktyce rozwiązania „techniczne", umożliwiające m.in. gromadzenie i opracowywanie dużych zasobów danych, zapewnianie dostępu do źródeł różnego rodzaju (głównie digitalizacja książek, czasopism, manuskryptów), w mniejszym stopniu natomiast takie, które pozwalają na tworzenie narzędzi komunikacji między badaczami czy gromadzenie i opracowywanie dużych zasobów danych. Taki stan rzeczy w Polsce odbiega - jak się wydaje - od sytuacji „zagranicznej”, gdzie pojawiają się różnego rodzaju próby modyfikacji dotychczasowych sposobów badania, zastosowania pomysłów z dziedziny Nowej Humanistyki do literatury dawnej czy przynajmniej otwierania przestrzeni, w której możliwa byłaby wymiana doświadczeń.

Wystarczy tu odwołać się do prac dotyczących emocji w dawnych wiekach, m.in. studiów Barbary Rosenwein czy obszernego tomu Sensible Moyen Âge. Une histoire des emotions dans l'Occident médieval pod redakcją Damiena Bouquet i Piroski Nagy. Tom ten wydany pod koniec 2015 roku jest dedykowany pamięci Jacques'a Le Goffa, zmarłego rok wcześniej jednego z patronów nowoczesnej mediewistyki i metodologa historii. Ten szczegół wydaje się wart odnotowania ze względu na zauważalną w wielu obszarach badań prowadzonych w Anglii, Francji czy Niemczech, mających odpowiedniki w kręgu Nowej Humanistyki, umiejętność podejmowania badań prowadzonych przez 
poprzedników w sposób nowy, odmienny, jednakże niezakładający budowania „od nowa", w próżni metodologicznego instrumentarium.

Spoglądając zaś z nieco innej perspektywy, można zauważyć, że wśród patronów Nowej Humanistyki zainteresowanie dawnymi wiekami i ich literaturą jest bardzo częste, podobnie łączenie przez nich w praktyce badawczej spojrzenia na wieki dawne i współczesność. By wymienić tylko kilka przykładów: Aleida Assmann poświęciła fundamentalną rozprawę, współkonstytuującą dzisiejszy sposób myślenia o pamięci, archeologii literackiej komunikacji, formom pamięci, posługując się przykładami z literatury dawnej, zaś podstawową specjalizacją badawczą Jana Assmanna pozostaje egiptologia (którą studiowała również jego żona). Hans Ulrich Gumbrecht jest romanistą, hispanistą, który w początkach drogi badawczej zajmował się literaturą dawną, a dziś buduje refleksję teoretyczną i studia szczegółowe na materiale od średniowiecza po współczesność. Friedrich Kittler teorie dotyczące funkcjonowania mediów w świecie współczesnym oparł na gruntownej analizie ich historycznych przemian w wieku XIX. Myślenie Marthy Nussbaum o politycznych emocjach rozpoczyna się od Rousseau, Herdera i Mozarta. Nie wymaga uzasadnienia podkreślenie zakorzenienia „nowego historyzmu" w badaniach epok dawnych, a popularność, jaką zdobył Zwrot Greenblatta, wyraźnie wskazuje na czytelność odwołań do dawnej tradycji we współczesnej refleksji humanistycznej. Przywoływanie historycznych studiów Michela Foucaulta od Historii szaleństwa po Historię seksualności wydaje się już w tym kontekście wręcz naddatkiem.

Oczywiście nie chodzi tu o mnożenie przykładów, ponieważ nie byłoby trudne wskazanie nazwisk badaczy, którzy prace fundamentalne dla nowej metodologii humanistycznej ograniczyli do współczesności i zaczerpniętego z niej materiału egzemplifikacyjnego. Zależało mi na podkreśleniu powtarzającego się wielokrotnie w dokonaniach ważnych i najważniejszych badaczy nowoczesnego literaturoznawstwa (i humanistyki) rozciągnięcia zainteresowań ze studiów nad epokami dawniejszymi na zjawiska należące do obszaru współczesności. Wzajemne naświetlanie się dawności i współczesności pozwala - w niektórych rzecz jasna przypadkach - prowadzić do spojrzenia rzeczywiście nowego, do odsłonięcia możliwości, które okazują się stosowalne na różnych obszarach, stają się składnikiem nowej metodologii.

Powróćmy do sytuacji polskiego literaturoznawstwa, wskazując inną perspektywę: w jaki sposób badania dawnej literatury próbują zmodyfikować instrumentarium badawcze przez otwarcie się na zjawiska z dziedziny (niekoniecznie tak nazywanej) Nowej Humanistyki. W kręgu badaczy literatury 
dawnej generalnie zainteresowanie problemami metodologicznymi nie jest znaczne, do rzadkości należą też polemiki w tym zakresie. Można wskazać kilka czy kilkanaście prac, w których próbowano stawiać pytania o takim charakterze, wymienić kilku badaczy: Krzysztofa Obremskiego, Andrzeja Dąbrówkę, Pawła Bohuszewicza, Piotra Oczko i Tomasza Nastulczyka, wspomnieć dyskusję sprzed dziesięciu lat z udziałem Mirosławy Hanusiewicz-Lavallee i Agnieszki Czechowicz w kwestii „podejścia filologicznego” do badań literatury staropolskiej, przywołać z dziedziny studiów nad oświeceniem prace Dobrochny Ratajczakowej i Macieja Parkitnego.

Niewiele jest też prac systematycznie stosujących nowe rozwiązania metodologiczne w praktyce badań nad literaturą i kulturą Pierwszej Rzeczypospolitej, przy czym zupełnie pozostawiam na marginesie kwestię, czy osiągnięte w ten sposób rezultaty są ważne poznawczo, czy byłyby możliwe do uzyskania metodami tradycyjnymi. Można poprzestać na stwierdzeniu niewielkiego zainteresowania badaczy polskiej literatury dawnej nowoczesnością metodologiczną, próbami zmiany powszechnie przyjmowanego, intuicyjnego w znacznej mierze, tradycyjnego sposobu postępowania badawczego. Na dobrą sprawę czasem wydaje się, że granica rozbiorów okazuje się nieprzepuszczalna dla metodologicznej zmiany (nie tylko z dziedziny Nowej Humanistyki).

Nowa Humanistyka z kolei, zanurzona we współczesności, nie wydaje się zainteresowana uzasadnianiem swojego istnienia i działania przez „dawność", która sięgałaby poza połowę XX stulecia. Analiza współczesności jest - i zawsze była - fascynującym zadaniem humanistycznym, natomiast wyraźną konsekwencją redukcji zainteresowania korzeniami współczesności, wczesną nowoczesnością, stawać się może - i będzie - nie(z)rozumienie właśnie samej współczesności wynikające często z przeświadczenia o jej wyjątkowości.

W tej perspektywie można i należy zapytać, w jakim stopniu Nowa Humanistyka jest gotowa do poddania obserwacji również „dawności” literackiej i kulturowej oraz jej trwania jako tradycji. Niewątpliwie konsekwencją stosowania w badaniach nad przeszłością - bliższą i bardziej odległą - metod Nowej Humanistyki może być reorganizacja nie tylko sposobów naukowego postępowania, ale również polskiej zbiorowej pamięci i wyobraźni, która nie będzie wynikała ze zmian o charakterze ideologicznym, ale z przekształceń refleksji humanistycznej. Zmiany te nie byłyby kwestią lat, ale dziesięcioleci, więc już dziś należy zastanowić się nad możliwymi obszarami spotkania współczesności i dawności, metod tradycyjnych i nowszych - i nad możliwym przemodelowaniem kształcenia na studiach polonistycznych, filologicznych, 
kulturoznawczych. I to właśnie sytuowałoby się w obszarze odpowiedzialnej refleksji nad ciągłością dawnej tradycji.

\section{Abstract}

\section{Marcin Cieński}

UNIVERSITY OF WARSAW

New Humanities and Responsibility for the Continuity of an (Early Modern) Tradition

In Polish literary and cultural studies, the New Humanities are a recent development, not yet fully formed and drawing on earlier methodological turns - a laboratory or sorts. Polish researchers focus on contemporary phenomena (from the mid-twentieth century), adapting their tools to them. They practically do not refer to older literatures and cultures, and consequently their work creates an image of the present that is rootless, devoid of tradition and memory. Outside Poland, by contrast, the scholars who represent the key reference points for the New Humanities have often developed their tools by exploring earlier literatures and cultures, for instance in their work on emotions. This exclusive interest in the present is worrying, as it ignores the important role of the old tradition and the continuity of culture - in research as well as in the literary and cultural education of new generations.

\section{Keywords}

New Humanities, methodological turn, literary tradition, early modern literature, collective memory, literary and cultural education 